\title{
Seismic Study of Multistorey Building using Floating Column
}

\author{
Sreadha A R, C.Pany
}

\begin{abstract}
Columns rest on the beam without foundation are called floating column. They are used commonly in multi-storey buildings which are purposed to hold parking at ground floor or open halls at higher floors. Discontinuation within the load transfer path is seen in this column. Thus they are designed for gravity loads. But these structures aren't designed for earthquake loads. In present scenario structures with floating column may be a common characteristic in urban India. However in tectonic areas, this type of structure is not preferred due to discontinuity of load transfer path i.e. whole earthquake load on the structure is shared by the shear walls without any loads on the floating columns. This paper review the nature of a multi-storey building under quake forces with and without of floating columns. This analysis focus the importance of specially identifying the presence of the floating column within the study of the struture, establish its correlation with the building without a floating column using designing software Extended three dimensional analysis of building systems (ETABS). This paper also discusses the performance of structure having floating column in seismically active areas. Besides these various parameter such as maximum displacement, effect on number of storey on drift, base shear are also studied.

Keywords : Floating columns, Equivalent static analysis, Storey displacement, Storey drift, Base shear, Etabs
\end{abstract}

\section{INTRODUCTION}

\section{A. General}

The vertical part of structure is called column which is used to carry structural load and transmit it through beams [1] while floating column is the one which rest on beam.In floating column the beam which support column act as a foundation and it should not go beyond foundation [2] as shown in Fig 1. They have disruption in the load shift direction.In Floor space index (FSIthe ratio of built up area to the plot area ) balconies are not counted as per building laws.Therefore building having balconies extend outwards within the top stories apart from the footprint area at the bottom storey projects up to 1.2 to $1.5 \mathrm{~m}$ in plan[3].Floating columns are given along the overhanging perimeters of the buliding. The periphery of columns of the bottom storey are discarded within top storey

In the present paper effect of floating column on construction of multi-storey building has been studied. The results on with and without floating column compared. Various parameters such as maximum displacement, effect on number of storey on drift, base shear are discussed. The material properties and section properties considered for analysis are shown in Table I \& II. Similarly, the seismic parameter details considered as per IS code[4,5] is shown in table III.

Manuscript Received on April 2, 2020.

*Correspondence Author

Sreadha A R*, Civil Engineering Department, Amal Jyothi College of Engineering \& Technology, Kanjirapally, India. Email: a.r.sreadha@gmail.Com

Dr. C.Pany, Engineer, VSSC, Trivandrum, Kerala, India Email: c_pany@yahoo.com

(C) The Authors. Published by Blue Eyes Intelligence Engineering and Sciences Publication (BEIESP). This is an open access article under the CC BY-NC-ND license (http://creativecommons.org/licenses/by-nc-nd/4.0/)

\section{B. Floating Column}

In floating column transfer of load to the column below it by the beam.The transfer of load in floating column changes from vertical to horizontal within the intermittent frame. In many cases these columns are choosen specially above bottom floor. Thus more open spaces is offered within ground floor which can be used for auditorium or parking intention[6].Thus floating column is additionally used in construction practice and it is avoided due to excess of beams. To maintain the stability of building the joint among beam and floating column are treated as critical.Main cause of collapse of this type of structure is the failure of large beam column specimens occurs in the joint in concrete moment resisting frame[7].The geometry of the considered model is shown in table IV.

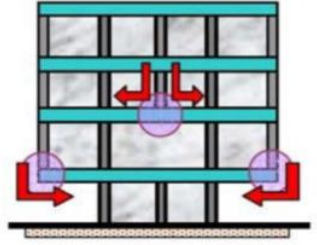

(a)

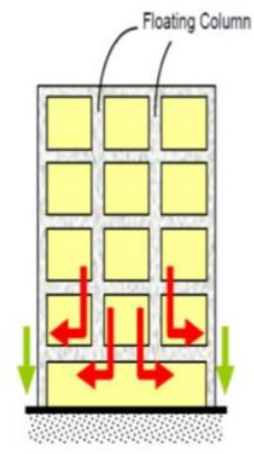

(b)
Fig 1: Buildings with floating column

a) at Ist and $2^{\text {nd }}$ floor [1][2][6][7]

b) the column is discontinued at a lower level [8]

\section{METHODOLOGY}

1. Using ETABS [9] 2016 software G+5 storey structure is modeled and studied.

2. Equivalent static analysis of structures and Response spectrum analysis (dynamic) is done. (Details of methods are given in section III)

\section{A. BUILDING CONFIGURATIONS}

For analysis three models considered as follows:

MODEL1- In model 1 structure without floating column is considered and is analyzed for zone 4. (Fig 2 \& Fig 3)

MODEL2- In model 2 floating column is introduced at $1^{\text {st }}$ floor at the outer section of the plan. This model is analyzed for zone4. (Fig 4 \& Fig 5) 


\section{Seismic Study of Multistorey Building using Floating Column}

MODEL 3- In model 3 floating column is introduced at $5^{\text {th }}$ floor at the outer section of the plan. This model is analyzed for zone4. (Fig 6 \& Fig 7)

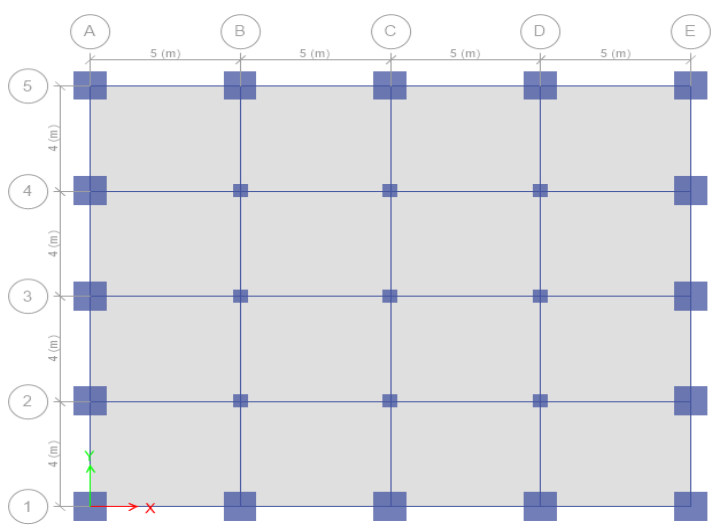

Fig 2 : Plan without floating column (Model 1)

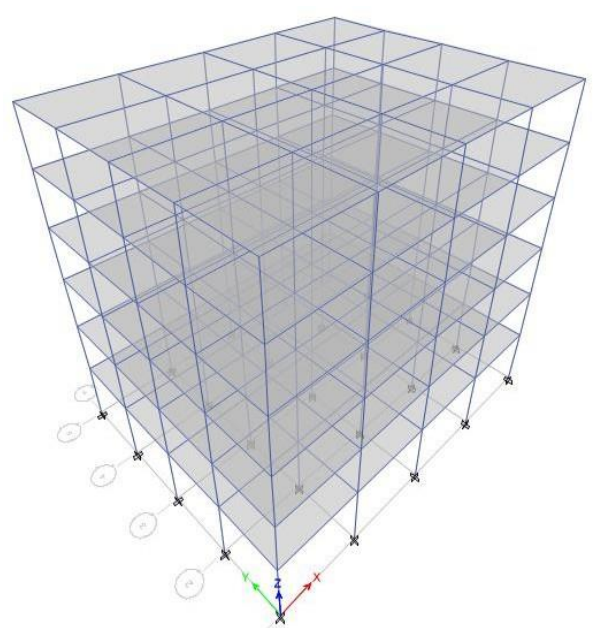

Fig 3: Three-dimensional view without floating column ( Model 1)

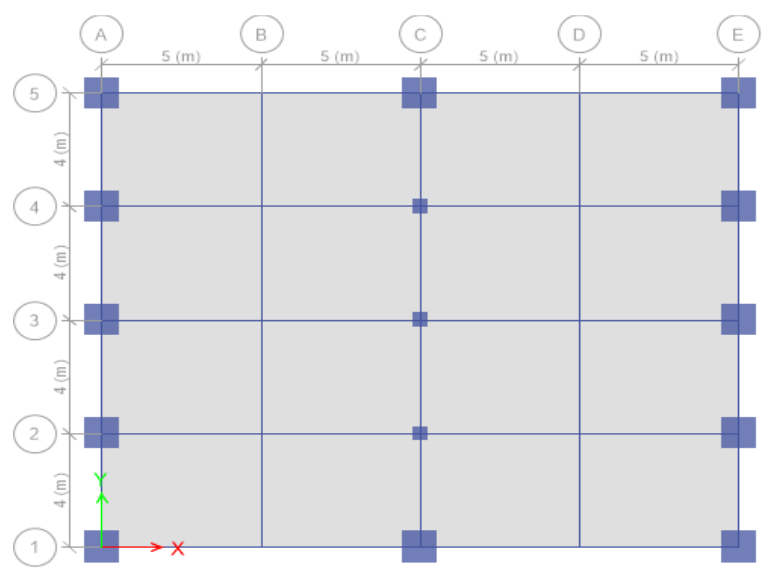

Fig 4 : Plan by floating column at $\mathrm{I}^{\text {st }}$ floor ( Model 2)

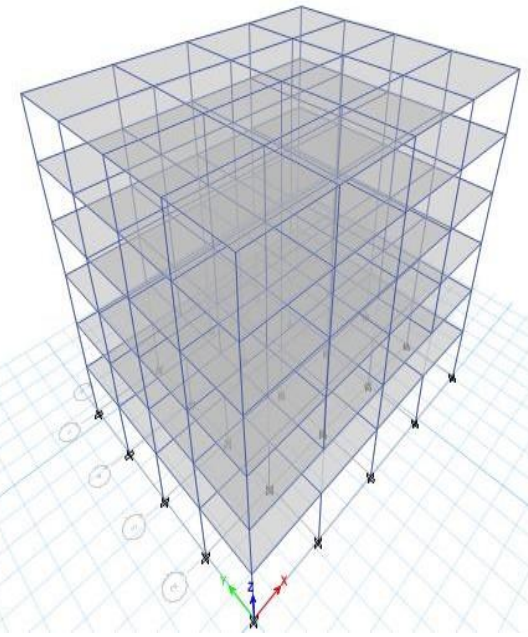

Fig 5 : Three-dimensional view by floating column at $\mathbf{I}^{\text {st }}$ floor (Model 2)

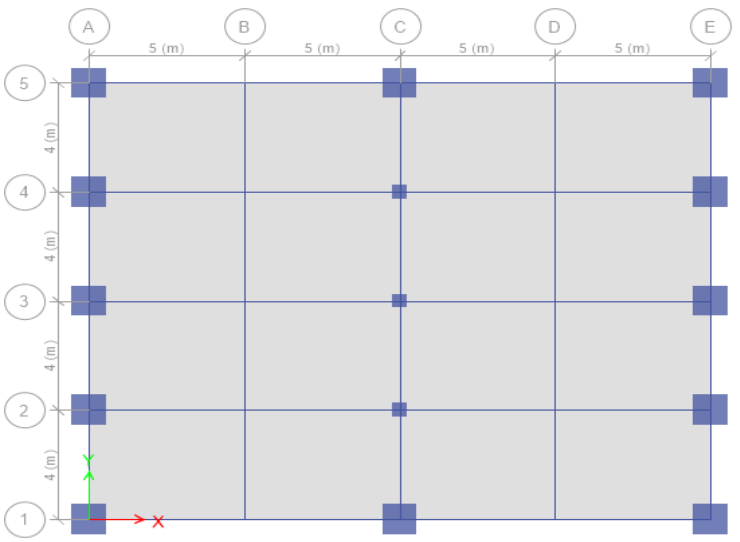

Fig 6: Plan by floating column at $5^{\text {th }}$ floor ( Model 3 )

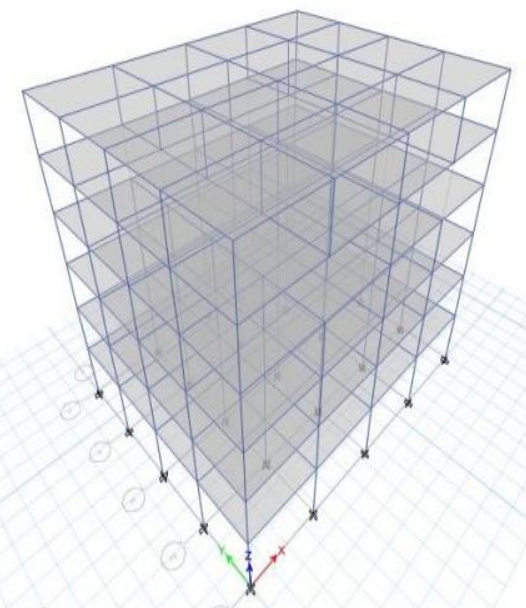

Fig 7 : Three-dimensional view by floating column at $5^{\text {th }}$ floor (Model 3) 


\section{B. MATERIAL PROPERTIES}

Table I: Properties of material

\begin{tabular}{|c|c|}
\hline Properties & Values \\
\hline $\begin{array}{c}\text { Characteristic compressive strength of } \\
\text { concrete, fck }\end{array}$ & $25 \mathrm{MPa}$ \\
\hline Yield stress for steel, fy & $415 \mathrm{MPa}$ \\
\hline Elastic modulus of Steel, Es & $20,0000 \mathrm{MPa}$ \\
\hline Elasticity modulus of concrete, Ec & $25000 \mathrm{MPa}$ \\
\hline
\end{tabular}

\section{SECTION PROPERTIES}

Table II: Building data [7]

\begin{tabular}{|c|c|c|c|}
\hline Parameters & $\begin{array}{l}\text { Structure } \\
\text { without } \\
\text { floating } \\
\text { column } \\
\text { ( Model 1) }\end{array}$ & $\begin{array}{c}\text { Structure } \\
\text { with floating } \\
\text { column at It } \\
\text { floor } \\
\text { ( Model 2) }\end{array}$ & $\begin{array}{c}\text { Structure } \\
\text { with floating } \\
\text { column at } 5^{\text {th }} \\
\text { floor } \\
\text { ( Model 3) }\end{array}$ \\
\hline $\begin{array}{c}\text { Length in X- } \\
\text { direction }\end{array}$ & 20 & 20 & 20 \\
\hline $\begin{array}{c}\text { Length inY- } \\
\text { direction }\end{array}$ & 16 & 16 & 16 \\
\hline $\begin{array}{l}\text { No. of } \\
\text { storeys }\end{array}$ & $\operatorname{Six}(G+5)$ & Six $(G+5)$ & $\operatorname{Six}(G+5)$ \\
\hline $\begin{array}{l}\text { Beam at } \\
\text { exterior }\end{array}$ & $\begin{array}{c}230 \times 550 \mathrm{~mm} \\
\text { M20 grade } \\
\text { concrete }\end{array}$ & $\begin{array}{c}230 \times 550 \mathrm{~mm} \\
\text { M20 grade } \\
\text { concrete }\end{array}$ & $\begin{array}{c}230 \times 550 \mathrm{~mm} \\
\text { M20 grade } \\
\text { concrete }\end{array}$ \\
\hline $\begin{array}{l}\text { Beam at } \\
\text { interior }\end{array}$ & $\begin{array}{c}230 \times 500 \mathrm{~mm} \\
\text { M20 grade } \\
\text { concrete }\end{array}$ & $\begin{array}{c}230 \times 500 \mathrm{~mm} \\
\text { M20 grade } \\
\text { concrete }\end{array}$ & $\begin{array}{c}230 \times 500 \mathrm{~mm} \\
\text { M20 grade } \\
\text { concrete }\end{array}$ \\
\hline $\begin{array}{c}\text { Transfer } \\
\text { beam }\end{array}$ & - & $\begin{array}{c}1.2 \mathrm{~m} \times 1 \mathrm{~m} \\
\mathrm{M} 45 \text { grade } \\
\text { concrete }\end{array}$ & $\begin{array}{c}1.2 \mathrm{~m} \times 1 \mathrm{~m} \\
\mathrm{M} 45 \text { grade } \\
\text { concrete }\end{array}$ \\
\hline I $^{\text {st }}$ Column & $\begin{array}{c}1.1 \mathrm{~m} \times 1.1 \mathrm{~m} \\
\text { M35 grade } \\
\text { concrete }\end{array}$ & $\begin{array}{c}1.1 \mathrm{~m} \times 1.1 \mathrm{~m} \\
\text { M35 grade } \\
\text { concrete }\end{array}$ & $\begin{array}{c}1.1 \mathrm{~m} \times 1.1 \mathrm{~m} \\
\text { M35 grade } \\
\text { concrete }\end{array}$ \\
\hline $2^{\text {nd }}$ Column & $\begin{array}{c}500 \times 500 \mathrm{~mm} \\
\text { M35 grade } \\
\text { concrete }\end{array}$ & \begin{tabular}{|c|}
$500 \times 500 \mathrm{~mm}$ \\
M35 grade \\
concrete
\end{tabular} & $\begin{array}{c}500 \times 500 \mathrm{~mm} \\
\text { M35 grade } \\
\text { concrete }\end{array}$ \\
\hline Slab & $\begin{array}{c}125 \mathrm{~mm} \\
\text { M20 grade } \\
\text { concrete }\end{array}$ & $\begin{array}{c}125 \mathrm{~mm} \\
\text { M20 grade } \\
\text { concrete } \\
\end{array}$ & $\begin{array}{c}125 \mathrm{~mm} \\
\text { M20 grade } \\
\text { concrete }\end{array}$ \\
\hline Live load & $3 \mathrm{kN} / \mathrm{m}^{2}$ & $3 \mathrm{kN} / \mathrm{m}^{2}$ & $3 \mathrm{kN} / \mathrm{m}^{2}$ \\
\hline Roof live & $1.5 \mathrm{kN} / \mathrm{m}^{2}$ & $1.5 \mathrm{kN} / \mathrm{m}^{2}$ & $1.5 \mathrm{kN} / \mathrm{m}^{2}$ \\
\hline Wall load & $12.42 \mathrm{kN} / \mathrm{m}^{2}$ & $12.42 \mathrm{kN} / \mathrm{m}^{2}$ & $12.42 \mathrm{kN} / \mathrm{m}^{2}$ \\
\hline Parapet load & $2.484 \mathrm{kN} / \mathrm{m}^{2}$ & $2.484 \mathrm{kN} / \mathrm{m}^{2}$ & $2.484 \mathrm{kN} / \mathrm{m}^{2}$ \\
\hline
\end{tabular}

\section{SEISMIC PARAMETERS DETAILS}

Table III: Seismic parameters details [8]

\begin{tabular}{|c|c|}
\hline Struture type & $\begin{array}{c}\text { Multi storied RC rigid jointed } \\
\text { plane frame (SMRF) }\end{array}$ \\
\hline Type of soil & Medium; Type-II \\
\hline Zone & IV \\
\hline Damping in structure & $5 \%$ \\
\hline Importance factor & 1.962 \\
\hline Scale Factor & 1 \\
\hline Time period & 5 \\
\hline $\begin{array}{c}\text { Response reduction } \\
\text { factor(R) }\end{array}$ & \\
\hline
\end{tabular}

Table IV: Geometry of the considered model [8]

\begin{tabular}{|c|c|c|c|c|c|c|}
\hline $\begin{array}{c}\text { No. of } \\
\text { ttorey' } \\
\text { s }\end{array}$ & $\begin{array}{c}\text { No of } \\
\text { opening } \\
\text { in X } \\
\text { directio } \\
\mathrm{n}\end{array}$ & $\begin{array}{c}\text { X } \\
\text { direction } \\
\text { bay } \\
\text { width }\end{array}$ & $\begin{array}{c}\text { No. of } \\
\text { opening } \\
\text { in Y } \\
\text { directio } \\
\mathrm{n}\end{array}$ & $\begin{array}{c}\text { Y } \\
\text { direction } \\
\text { bay } \\
\text { width }\end{array}$ & $\begin{array}{c}\text { Height } \\
\text { of } \\
\text { bottom } \\
\text { storey }\end{array}$ & $\begin{array}{c}\text { Height } \\
\text { of } \\
\text { storey }\end{array}$ \\
\hline 6 & 5 & 5 & 4 & 4 & 3.5 & 3 \\
\hline
\end{tabular}

\section{SEISMIC ANALYSIS OF STRUCTURE}

\section{A. EQUIVALENT STATIC ANALYSIS}

The method is done based on code IS 1893(part 1)-2002[10]. For entire building the design base shear is calculated.Computed results are assigned alone the elevation of structure.Lateral forces obtained are delivered to individual load resisting elements[11].The theoretical calculation part is as follows:

1) Design base shear $V_{B}=A_{h} W$

Where, $\mathrm{W}=$ Seismic weight of building

$A_{h}=$ Horizontal tectonic coefficient

Horizontal tectonic coefficient $A_{h}=\frac{Z_{\text {I S }}}{2 \mathrm{Rg}}$

Where, $\mathrm{Z}=$ Zone factor

$\mathrm{I}=$ Importance factor

$\mathrm{R}=$ Response reduction factor

$\mathrm{S}_{\mathrm{a}} / \mathrm{g}=$ Average response acceleration coefficient

2) Vertical distribution of base shear

$$
\mathrm{Q}_{\mathrm{i}}=\mathrm{V}_{\mathrm{B}} \frac{W i h i^{2}}{\sum_{j=1}^{n} W j h j^{2}}
$$

Where , $\mathrm{Q}_{\mathrm{i}}=$ Design lateral force

$\mathrm{W}_{\mathrm{i}}=$ Seismic weight of floor

$\mathrm{h}_{\mathrm{i}}=$ Height of floor measured from base of structure $\mathrm{n}=$ No of storeys

3) Horizontal distribution of base shear

$$
\mathrm{F}_{\mathrm{ij}}=\frac{K_{i j}}{\sum_{k=1}^{n k} K_{i k}} F_{i}
$$

Where, $F_{i j}=$ Force acting on the lateral force resisting line $\mathrm{j}$ at floor level $\mathrm{i}$

$\mathrm{nk}=$ No of lateral force resisting element 


\section{Seismic Study of Multistorey Building using Floating Column}

$\mathrm{K}_{\mathrm{ij}}, \mathrm{K}_{\mathrm{ik}}=$ Storey stiffness of lateral force resisting element line $\mathrm{k}$ and $\mathrm{j}$ at level $\mathrm{i}$

$\mathrm{F}_{\mathrm{i}}=$ Tectonic force acting at floor

4) Determination of drift, overtuning moment and Pdelta effect.

Drift storey $=\frac{\text { Variance in deflection between two adjoining floors }}{\text { Height }}$

- Overtuning moment and P- delta effect

Overturn of struture occur due to moment generate by equivalent static lateral force.Therefore it must be checked since dead weight of buildng is inadequate to resist .

Stability Coefficient $\Theta=\frac{P_{i} \Delta_{i}}{V_{i} h_{i}}$

$\mathrm{P}_{\mathrm{i}}=$ Weight of structure above storey

$\Delta_{\mathrm{i}}=$ Design storey drift

$\mathrm{V}_{\mathrm{i}}=$ Total sum of lateral tectonic design forces acting above storey

$\mathrm{h}_{\mathrm{i}}=$ Storey drift

\section{B. RESPONSE SPECTRUM METHOD}

Dynamic evaluation ought to be completed with a view to obtain the design seismic force and its distribution to different level along height of the structure and to distinctive lateral load resisting components. There are theoretical benefits in the use of the seismic analysis response spectrum approach to predict. This approach includes the measurement of only the maximal values of the displacements and of the component forces in each mode of vibration using a smooth design spectra that is the sum of many earthquake movements[12].Code used for analysis of multi-story building IS:1893 (Part 1)-2002[10].

\section{RESULTS AND DISCUSSIONS}

\section{A. STATIC ANALYSIS}

\section{a. Storey displacement}

Displacement of storey relative to base of struture is called storey displacement.Most significant and most clearly evident point of contrast for structure is deflected shape[11]. The utmost displacements of building in different stories for all models have been compared. The results are taken for zone 4 with medium soil condition. The results are shown in table $\mathrm{V}$ as floor wise. Storey displacement variations are shown in fig no 8. From graph it can be conclude that model 1 is showing min displacement and model 2 and 3 showing max displacement.

Table V: Comparison of displacement with and without floating columns

\begin{tabular}{|c|c|c|c|}
\hline & Model 1 & Model 2 & Model 3 \\
\hline Storey & $\mathrm{U}_{\mathrm{Y}}$ in mm & $\mathrm{U}_{\mathrm{Y}}$ in mm & $\mathrm{U}_{\mathrm{Y}}$ in mm \\
\hline 6 & 5.811 & 6.614 & 6.612 \\
\hline 5 & 4.815 & 5.495 & 5.541 \\
\hline 4 & 3.699 & 4.241 & 4.225 \\
\hline 3 & 2.524 & 2.914 & 2.868 \\
\hline 2 & 1.398 & 1.614 & 1.582 \\
\hline 1 & 0.489 & 0.527 & 0.552 \\
\hline Base & 0 & 0 & 0 \\
\hline
\end{tabular}

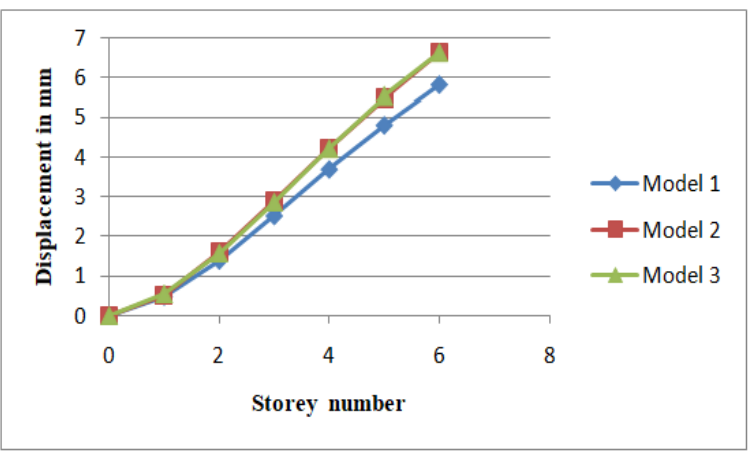

Fig 8: Comparison of displacement with and without floating columns

\section{b. Storey Drift}

Displacement of one storey relative to other storey is called storey drift[11]. The results are taken for zone 4 with medium soil condition.The results are shown in table VI as floor wise.Storey drift variations are shown in fig no 9. From graph it can be conclude that model 1 is showing min drift and model 2 and 3 showing max drift.

Table VI : Comparison of drift with and without floating columns

\begin{tabular}{|c|c|c|c|}
\hline & Model 1 & Model 2 & Model 3 \\
\hline Storey & Drift Y in mm & Drift Y in mm & Drift Y in mm \\
\hline 6 & 0.000336 & 0.000377 & 0.000371 \\
\hline 5 & 0.000372 & 0.000418 & 0.000443 \\
\hline 4 & 0.000392 & 0.000445 & 0.000454 \\
\hline 3 & 0.000376 & 0.000436 & 0.00043 \\
\hline 2 & 0.000304 & 0.000375 & 0.000345 \\
\hline 1 & 0.00014 & 0.000151 & 0.000158 \\
\hline Base & 0 & 0 & 0 \\
\hline
\end{tabular}

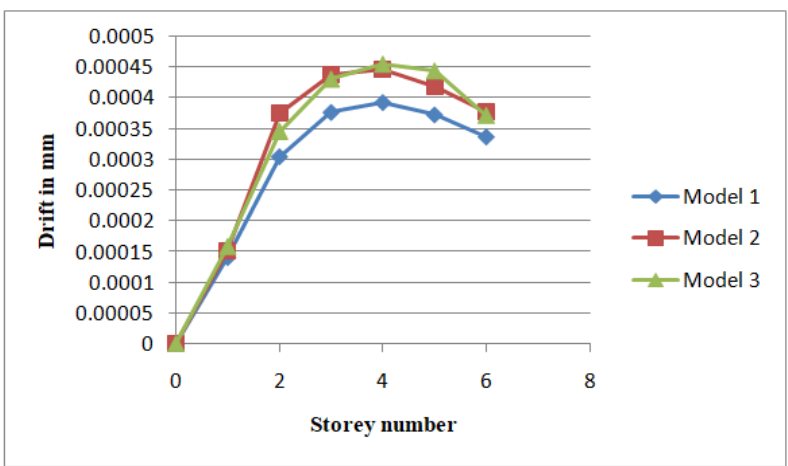

Fig 9: Comparison of drift with and without floating columns

\section{c. Base Shear}

Approximate calculation of maximum anticipated lateral force at the base against quake load is called base shear. Wherever structure is fixed base shear will act[11].The results are taken for zone 4 with medium soil condition. 
Results are shown in table VII as floor wise.Storey drift variations are shown in fig no 10 . From graph it can be conclude that base shear is more for buildings without floating column and decreases for building with floating column

Table VII: Comparison of base shear with and without floating columns

\begin{tabular}{|c|c|c|c|}
\hline & Model 1 & Model 2 & Model 3 \\
\hline Storey & $\mathrm{V}_{\mathrm{X}}$ in $\mathrm{kN}$ & $\mathrm{V}_{\mathrm{X}}$ in $\mathrm{kN}$ & $\mathrm{V}_{\mathrm{X}}$ in $\mathrm{kN}$ \\
\hline 6 & 273.35 & 293.36 & 252.07 \\
\hline 5 & 534.42 & 573.53 & 670.10 \\
\hline 4 & 704.20 & 755.74 & 814.49 \\
\hline 3 & 802.27 & 860.98 & 904.93 \\
\hline 2 & 848.18 & 946.54 & 947.16 \\
\hline 1 & 862.08 & 960.34 & 959.97 \\
\hline Base & 0 & 0 & 0 \\
\hline
\end{tabular}

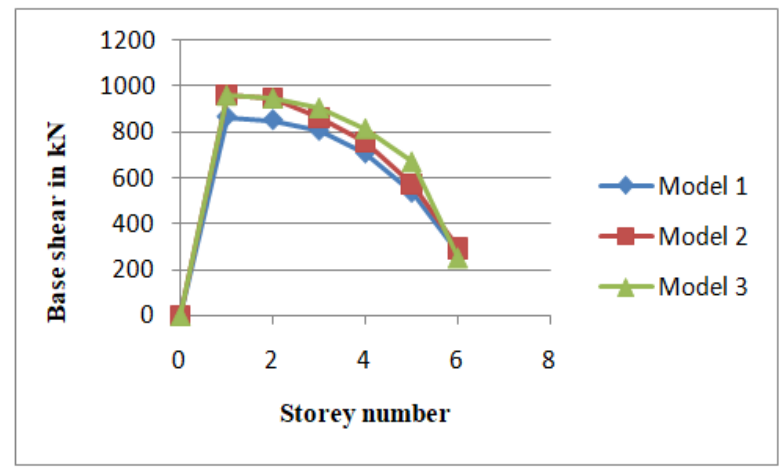

Fig 10: Comparison of base shear with and without floating columns

\section{B. RESPONSE SPECTRUM ANALYSIS}

\section{a. Storey displacements}

The results are taken for zone 4 with medium soil condition.The results are shown in table VIII as floor wise. Storey displacement variations are shown in fig no 11. From graph it can be conclude that model 1 is showing min displacement and model 2 and 3 showing max displacement.

Table VIII: Comparison of displacements with and without floating columns

\begin{tabular}{|c|c|c|c|}
\hline & Model 1 & Model 2 & Model 3 \\
\hline Storey & $\mathrm{U}_{\mathrm{Y}}$ in mm & $\mathrm{U}_{\mathrm{Y}}$ in mm & $\mathrm{U}_{\mathrm{Y}}$ in mm \\
\hline 6 & 48.213 & 53.441 & 57.407 \\
\hline 5 & 40.27 & 44.778 & 48.433 \\
\hline 4 & 31.278 & 34.973 & 37.287 \\
\hline 3 & 21.613 & 24.378 & 25.556 \\
\hline 2 & 12.124 & 13.769 & 14.241 \\
\hline 1 & 4.295 & 4.563 & 5.019 \\
\hline Base & 0 & 0 & 0 \\
\hline
\end{tabular}

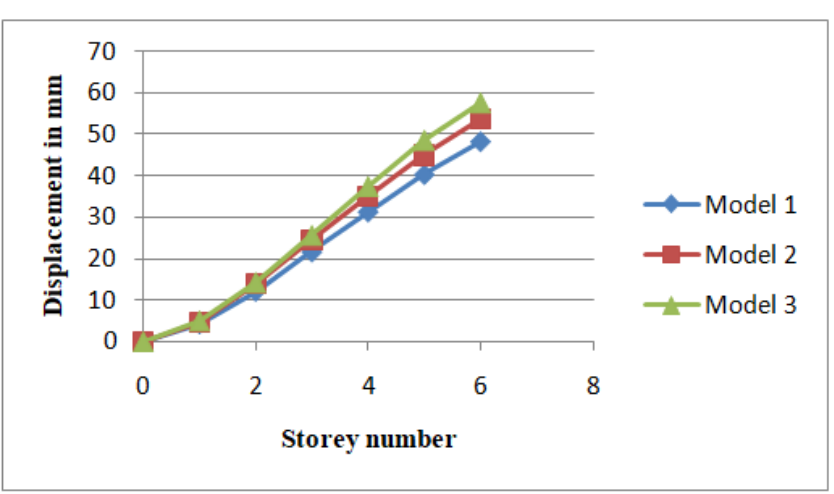

Fig 11: Comparison of displacement with and without floating columns

\section{b. Storey Drift}

The results are taken for zone 4 with medium soil condition.The results are shown in table IX as floor wise.Storey drift variations are shown in fig no 12. From graph it can be conclude that model 1 is showing min drift and model 2 and 3 showing max drift

Table IX: Comparison of drift with and without floating columns

\begin{tabular}{|c|c|c|c|}
\hline & Model 1 & Model 2 & Model 3 \\
\hline Storey & Drift Y in mm & Drift Y IN mm & Drift Y in mm \\
\hline 6 & 0.002703 & 0.00295 & 0.003126 \\
\hline 5 & 0.003015 & 0.003293 & 0.003769 \\
\hline 4 & 0.003234 & 0.003571 & 0.00393 \\
\hline 3 & 0.003169 & 0.003573 & 0.003786 \\
\hline 2 & 0.002621 & 0.003177 & 0.003088 \\
\hline 1 & 0.001227 & 0.001304 & 0.001434 \\
\hline Base & 0 & 0 & 0 \\
\hline
\end{tabular}

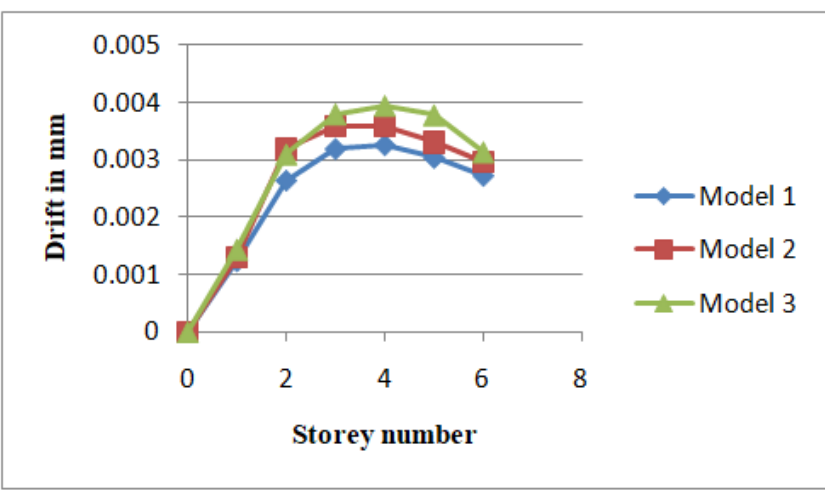

Fig 12: Comparison of drift with and without floating columns 


\section{Seismic Study of Multistorey Building using Floating Column}

\section{CONCLUSION}

Now a days usage of floating column is increasing in multistorey building structural design. This is due to space \& aesthetic functional requirement are being fulfilled, thus notable to a raise in their necessity in residential and commercial buildings. However by analyzing seismic behavior of floating column, it can be concluded that seismic prone area, building with floating column exhibit higher storey drift and storey displacement compared to building without floating column. The detail of comparison with and without floating column are summarised below.

- Structure with floating column shows maximum displacement when compare to the structure without floating column

- With increase in storey number displacement increase, that is from lower to higher storey displacement increase

- When floating column is shifted towards higher storey lateral displacement increases

- $\quad$ Structure without floating column shows minimum storey drift while with floating column shows maximum storey drift.

- $\quad$ Structure without floating column shows minimum base shear while with floating column shows maximum base shear

Further it can be conclude that floating column at higher floor must be avoided in high rise building design.

\section{REFERENCES}

1. Jaswinder Singh, Kshipra Kapoor(2019), "Seismic Analysis of Multistoried Buildings with Floating Columns”, International Journal for Research in Applied Science \& Engineering Technology, Volume 7 Issue III, ISSN: 2321-9653

2. A.P. Mundada, S.G. Sawdatkar (2014), "Comparative Seismic Analysis of Multistorey Building with and without Floating Column' International Journal of Current Engineering and Technology, Vol.4, No.5

3. Avinash Pardhi, Parakh Shah, SatishYadav, Pundlik Sapat, Amit Kumar Jha(2016), "Seismic Analysis Of Rcc Building With \& Without Floating Columns", International Journal of Advanced Technology in Engineering and Science, Vol No 4,Issue No 3

4. IS : 875 ( Part 1 ) - 1987 Code of practice for design loads (other than earthquake) for buildings and structures

5. IS : 875 ( Part 2 ) - 1987 Code of practice for design loads (other than earthquake) for buildings and structures

6. Sarita Singla, Ashfi Rahman (2015), "Effect of Floating Columns on Seismic Response of Multi-Storeyed RC Framed Buildings", International Journal of Engineering Research \& Technology, Vol. 4 Issue 06

7. Preethi , Sudha PH, Maganur D S (2017), "Study The Behaviour Of Seismic Evaluation Of Multistoried Building With Floating Columns" International Journal of Scientific Engineering and Applied Science, Volume-3, Issue-9

8. Altaf Husain, Kailash Narayan(2018), "Seismic Response of Multistory Building with Floating and Setback Columns", International Journal of Engineering Research in Mechanical and Civil Engineering, Vol 3, Issue 5

9. ETABS 2016 Package

10. IS 1893(Part 1):2002 Criteria for Earthquake Resistant design of structures: General provisions and buildings

11. S.B. Waykule, Dr. C.P. Pise ,C.M. Deshmukh, Y.P. Pawar, S.S. Kadam, D. D. Mohite, S.V. Lale(2016), "Study of behaviour of floating column for seismic analysis of multistorey building" International Journal of Civil Engineering and Technology, Volume 7, Issue 6, pp. 676-685.

12. www.nptel.ac.in

\section{AUTHORS PROFILE}

Sreadha A R, holds B-Tech degree in Civil engineering from Heera college of engineering and technology, Trivandrum, Kerala in 2018. At present she is final year student pursuing master`s degree in computer aided structural engineering from Amal jyothi college of engineering and technology, Kanjirapally, Kerala.

Dr. C.Pany, is working as an Engineer in Structural engineering entity, Vssc, Trivandrum. He has published more than 30 research papers in journal \& conference proceeding. His research interest is in field of structural mechanics, structural dynamics ,composite strutures 